\title{
First France Argentine International Symposium on Biorheology
}

\section{FIRST ANNOUNCEMENT}

The First France-Argentine International Symposium on Biorheology will be held in Rosario, Argentine, September 9 to 11,1996 . It is sponsored by French Society of Fundamental and Clinic Biorhgeology (Chairman J.F.Stoltz) and Asociacion Argentina de Reologia (Chairman R.J.Rasia).

The Organizing Committee would like to extend our cordial invitation to all peoples to attend, the First France-Argentine International Symposium. The main themes of the symposium are biophysics of cell-cell interaction, biophysics of cell-tissue interaction, hemorheology and blood circulation, molecular structure and biorheological function, hemodynamics, clinical hemorheology, properties and function of biological fluids and tissues, rheological properties of drugs, pharmaceutical products and cosmetics and biorheology in biotechnology, and for promoting the exchanges of scholar achievements and cooperation on biorheology. September is the best season for you to enjoy the wonderful scene of Parana River and its islands.

Dates:From September 9 to 11, 1996.

Place : Rosario, Argentine

Call for papers : Deadline for receiving papers : May 1, 1996. All submitted papers should be made camera ready in English (A4 sheets) with a typing area of $165 \times 260 \mathrm{~mm}$ and must not be longer than four pages. An abstract (typing area $165 \times 100 \mathrm{~mm}$ ) must be added.

Accommodations : There are several hotels at Rosario the rate will be as follows:

Single Room : from US $\$ 50$ to US $\$ 100$ per night

Double Room : from US $\$ 60$ to US\$ 120 per night

Registration fee : US\$ 300 (for delegates) (about FF 1500) including proceedings, welcoming party, two lunchs, coffee breaks and one day tour.

If you wish to be included on the circulation list, and for further information concerning this Symposium, please contact Prof. J.F.STOLTZ or Prof. J. RASIA-VALVERDE at the following addresses:

Prof. Jean François STOLTZ

Hématologie

Fac. de Médecine - Univ. « Henri Poinoaré » - BP 184

54500-Vandoeuvre-lès-Nancy

France

Tel : (33) 83.59.28.75 - FAX : (33) 83.59.26.43 - E-Mail:stoltz@hemato.u-nancy.fr

Prof. Juana RASIA - VALVERDE

IFIR (CONICET - Univ. N. de Rosario)

Bvrd. 27 de Febrero 210 bis

2000 - Rosario

Tel: (54) 41-85.3222 - FAX : (54) 41-82.1772 - E-Mail : rasia@ifir.edu.ar 